\title{
Introduction - Entrepreneurship and the firm: Austrian perspectives on economic organization
}

\author{
Nicolai J. Foss and Peter G. Klein
}

During the last 25 years the theory of the firm, or more broadly, organizational economics, has become one of the hottest areas of applied microeconomics (see Foss, 2000). It has had a strong impact upon business administration, particularly the organization and strategy fields. Though important insights into the economics of organization were offered much earlier by Knight (1921), Coase (1937), Penrose (1959), Richardson (1960), Malmgren (1961) and others, it was only in the 1970 s that a systematic body of literature emerged explaining firms' existence, boundaries, internal organization and financial structure in terms of economic principles. The key insights have also been applied to joint ventures, franchise agreements, long-term supply contracts and a host of other institutional arrangements, so that organizational economics may be described as a general theory of economic organization.

Important strands of this literature are the transaction cost theory of the firm (Klein, Crawford and Alchian, 1978; Williamson, 1985) and the property rights approach (Grossman and Hart, 1986; Hart and Moore, 1990). Both focus on the relationship between asset characteristics and efficient ownership structures. Both, and perhaps particularly the property rights approach, are increasingly popular within mainstream microeconomics. Agency theory, which emphasizes the moral-hazard problem associated with delegated authority, has become the standard language of corporate finance (Jensen and Meckling, 1976; Fama and Jensen, 1983). The resource-based or capabilities theory of the firm offers yet another approach to firm boundaries, using firmspecific knowledge to explain diversification, market entry and other strategic decisions (for example, Teece et al., 1994; Langlois and Foss, 1999).

To be sure, these modern theories of the firm have made tremendous headway in understanding the determinants of the make-or-buy decision, the allocation of decision rights inside firms, the sources of authority and other problems of immense practical importance. However, important puzzles remain. As Bengt Holmström and John Roberts (1998) recently observed, 
organizational economics says little about coordination problems that result not from misaligned incentives, but from defective, incomplete or inconsistent knowledge (see also Langlois and Foss, 1999). For example, the property rights approach assumes symmetric information between the contracting parties, while agency models typically treat the principal as fully informed about the agent's available options (Foss 1999).

Moreover, organizational economics largely suppresses the study of experimentation, adaptation, learning, and other processes. Decision-makers are modelled as if they can choose efficient contractual forms, allocations of property rights, or governance structures on an ex ante basis, leaving little room for ex post governance. This approach raises certain logical puzzles: agents, for instance, are held to be boundedly rational with respect to certain variables but substantively rational with respect to others (Kreps, 1996). Moreover, theories of ex ante coordination are ill-suited for explaining the experimental aspects of economic organization, such as mergers and other business recombinations that are later 'undone' through divestiture or reorganization (Klein, 1999; Klein and Klein, 2001).

Related to the suppression of knowledge and process in these modern theories is their suppression of entrepreneurship. For example, the creation of new markets through the exercise of entrepreneurship receives little attention in the modern economics of organization (Casson, 1997). This suggests that the theory of the firm, while increasingly mature, is far from fully developed. Traditionally, the theory of the firm has taken much inspiration from business administration, sociology and other theories that lie somewhat outside of the economic mainstream. For example, Williamson's (1985) work draws on the thought of (old) institutionalist economist John Commons and the legal theorist Karl Llewellyn. And contributors to the capabilities view of the firm have drawn on evolutionary economics. This suggests that organizational economics may benefit from further exposure to unorthodox perspectives.

As the modern theory of the firm was taking shape in the 1970s, another important movement in economics was emerging: a revival of the 'Austrian' tradition in economic theory. The Austrian school of economics, named for the Viennese professor Carl Menger and his students and followers, offered a unique account of the pricing process, the structure of capital, and the causes of economic fluctuations that differed sharply from the Marshallian, Walrasian and Keynesian approaches that came to dominate the economics profession. Like the other marginalists William Stanley Jevons and Léon Walras, Menger emphasized subjectively held consumer wants as the source of economic value (as opposed to the classical view that production costs determined value). Unlike the neoclassical approach, however, Menger's approach to economics was causal, systematic and realistic, seeking to explain real-world prices and institutions in terms of the values, plans and actions of 
market participants. Austrian economists have thus generally eschewed mechanical, general equilibrium analysis and relied on verbal reasoning to elucidate economic theory.

The Austrian school rose to prominence in the late nineteenth and early twentieth centuries under the influence of Menger, Eugen von Böhm Bawerk, Frank A. Fetter, Herbert J. Davenport, Philip Wicksteed, Ludwig von Mises, Lionel Robbins and F.A. Hayek, but fell into obscurity by the end of the 1930s. ${ }^{1}$ Important work in the Austrian tradition was later done by Mises (1949, 1957, 1962), Rothbard (1956, 1962, 1963a, 1963b), Kirzner (1963, 1966, 1973) and Lachmann (1956), but at least publicly, the Austrian tradition lay mostly dormant.

When the 1974 Nobel Prize in economics went to Hayek, interest in the Austrian school was suddenly and unexpectedly revived. While this was not the first event of the so-called 'Austrian revival' (Vaughn, 1994), the memorable South Royalton conference having taken place earlier the same year, the rediscovery of Hayek by the economics profession was none the less a decisive event in the renaissance of Austrian economics. ${ }^{2}$ Since then, the Austrian movement has flourished, and the modern Austrian school now features its own academic journals, professional societies, graduate programmes, and sponsoring organizations.

While characteristically Austrian ideas such as entrepreneurship, economic calculation, tacit knowledge, the temporal structure of capital and related issues are clearly relevant to management, organization and strategy, Austrian economists have said relatively little about the business firm. During the last decade, however, several dozen works relating Austrian economics to the theory of the firm have appeared (see the Reference section). To assess this literature, and discuss the significance of Austrian ideas for the theory of the firm more generally, we brought together scholars from several fields for a two-day conference in August 1998 at the Copenhagen Business School. The present volume collects 12 of the papers from the conference along with this introduction.

Although the authors come from diverse backgrounds and the chapters address a wide variety of theoretical and applied topics, all the authors share the view that Austrian insights have something to offer students of firm organization. Throughout its history, the Austrian school developed many of its key ideas as alternatives to other, more dominant perspectives. Menger's subjectivist, marginalist approach challenged the classical theory of value, and Menger later engaged the German Historical School in a lengthy debate on the proper scope and method of economics. Mises refined his views on monetary calculation during the socialist calculation debate, and Hayek developed and extended his and Mises's theory of business cycles in the course of several encounters with Keynes. Similarly, the essays collected here challenge 
important aspects of other, more mainstream perspectives on economic organization. However, the emphasis is on constructive engagement, rather than criticism per se.

The volume opens with Brian Loasby's chapter, 'Explaining Firms'. Loasby argues that the firm ultimately exists because knowledge is incomplete, fragmented, ambiguous, and often difficult to express in usable form. In particular, the notion that firms are important agents of exchange should be particularly attractive to Austrian economists: it focuses on entrepreneurial alertness as the foundation of a business that is created by making a market. Thus, as Loasby points out, 'to understand markets, we need a theory of the firm as market-maker'. In 'Modularity in Technology and Organization' Richard Langlois also addresses both firms and markets in terms of a unified framework inspired by Austrian economics. However, his main interest is in developing the outlines of a modularity theory of the firm. Langlois's theory conceptualizes firms in terms of the partitioning of rights understood in a Hayekian manner as protected spheres of authority - among cooperating parties. Basically, firms reflect 'non-modular' structures, that is, structures in which decision rights, rights of alienation and residual claims to income do not all reside in the same hands.

A focus on modularity has also implicitly been present in much recent discussion of economic organization in the emerging knowledge economy. Thus, many authors have argued that organizational elements are essentially modular, and therefore more or less combinable at will. Nicolai Foss's chapter, 'Economic Organization in the Knowledge Economy: An Austrian Perspective,' takes issue with such claims, arguing that although Hayekian ideas provide insights into ongoing transformations of economic organization towards flatter hierarchies, more extensive delegation of decision rights, and so on, insights into property rights developed by Ludwig von Mises helps us to understand why hierarchical firms are likely to serve as discrete governance structures, even in the emerging knowledge economy. However, as Pierre Garrouste ('Knowledge: A Challenge for the Austrian Theory of the Firm') argues, 'knowledge', and particularly learning, is indeed 'a challenge for the Austrian theory of the firm'; in particular, the understanding of the interaction between processes of learning and the provision of incentives is underdeveloped, not only in Austrian flavoured contributions to the theory of the firm, but certainly also, as Loasby points out, in the mainstream economics of organization.

Like learning, entrepreneurship is something of a challenge to theory of the firm. Not surprisingly, since entrepreneurship is a key Austrian interest, a number of the chapters are taken up with examining the relation between entrepreneurship and the theory of the firm. Thus, Wolfgang Gick ('Schumpeter's and Kirzner's Entrepreneur Reconsidered: Corporate 
Entrepreneurship, Subjectivism and the need for a Theory of the Firm') tries to reconcile the Kirznerian and the Schumpeterian entrepreneur in a way that differs from Kirzner's own (and others') reconciliation exercise(s). In particular, Gick's treatment is informed by empirical findings on the organization of innovative activities. He also argues that Schumpeter and Kirzner's theories of entrepreneurship need theories of the firm; both are criticized for paying excessive attention to market phenomena and forgetting about the 'embodiment' of entrepreneurship in firms. In contrast, the papers by Kirsten Foss and Nicolai Foss ('Economic Organization and the Trade-offs between Productive and Destructive Entrepreneurship'), Stavros Ioannides ('Entrepreneurship, Contracts and the Corporate Firm: Austrian Insights on the Contractual Nature of Business Organization'), and Martti Vihanto ('Costs of Contracting, Psychology of Entrepreneurship and Capabilities of Firms') all argue that Austrian insights into entrepreneurship will substantially enrich the mainstream theory of economic organization.

Thus, Foss and Foss use Austrian insights into knowledge, entrepreneurship and ownership to investigate the issues of who in a productive relation between two individuals will be principal and who will be agent, and what is the optimal degree of contractual incompleteness when there are both costs and benefits of 'empowering' the agent. None of these issues are treated in the standard principal-agent model. Like Foss and Foss, Ioannides investigates the implications of entrepreneurship for comparative contracting. He also argues that the phenomenon of entrepreneurship casts new light on ownership, and that, in turn, ownership is important for understanding the opportunity set of the entrepreneurial firm. Vihanto draws in an innovative manner on psychological research to provide a more realistic account of contracting costs, and combines this with ideas of entrepreneurship. In particular, Vihanto is taken up with analysing the contracting costs that the entrepreneur-coordinator confronts, in the process making links to capabilities theories of the firm.

While also adopting the position that Austrian theories of entrepreneurship may usefully inform the theory of economic organization, the chapters by Peter Klein and Sandra Klein ('Do Entrepreneurs make Predictable Mistakes? Evidence from Corporate Divestitures') and Jerry Ellig ('Telecommunications Mergers and Theories of the Firm') have a more applied focus. Thus, drawing on a Misesian interpretation of entrepreneurship, Klein and Klein develop an experimental approach to merger activity and apply Austrian politicaleconomy insights to argue that regulatory activity is crucial for understanding 'mistaken integration'. They relate these ideas to the existing empirical evidence. Ellig argues that Austrian economics and capabilities theories share a concern with knowledge that is costly to communicate and transfer; indeed, to a certain extent, Austrian economics may be seen as a precursor of 
capabilities ideas. He demonstrates that these ideas have explanatory power by analysing the many large telecommunications mergers have been announced and consummated in the United States since the later 1990s.

Finally, and also falling in the more 'applied' category, are the papers by Peter Lewin and Stephen Phelan ('Rents and Resources: A Market Process Perspective') and Shelby Hunt ('Resource-Advantage Theory and Austrian Economics'). Lewin and Phelan begin from the resource-based theory in strategic management. A central concept in this theory is the well-known economic concept of 'rent'. They examine and reformulate the theory of rent along Austrian lines (more specifically, along the lines of the work of Austrian economist Frank A. Fetter) and relate it to the concept of equilibrium and the theory of competition in order to arrive at a more consistent and satisfactory basis for the resource-based theory of strategy and the firm. Finally, Shelby Hunt provides an assessment of the approach to firm strategy that he has been instrumental in developing - namely, 'resource-advantage theory' - from the perspective of Austrian economics. Since Austrian economics is included in the pedigree of resource-advantage theory, there is a considerable overlap. However, Hunt also argues that resource-advantage theory may provide a foundation for an Austrian theory of competition, particularly because resource-advantage theory is more explicitly taken up with the dynamically competitive activities of firms competing in disequilibrium situations on the basis of their heterogeneous resource bundles.

To sum up, what is offered in the present collection is a dozen chapters that all innovatively apply key Austrian ideas to crucial issues of economic organization and firm strategy. Because of the relative novelty of the present undertaking, there is an explorative dimension to most of the chapters. We hope that the ideas expressed in these chapters will encourage the further integration of Austrian ideas into the economics of organization.

\section{NOTES}

1 Explanations for the Austrian school's decline are offered in Vaughn (1994) and Salerno (1999).

2 The proceedings of the South Royalton conference were published as The Foundations of Modern Austrian Economics (Dolan, 1976). A follow-up volume appeared two years later: New Directions in Austrian Economics (Spadaro, 1978). For perspectives on the Austrian revival, see Rothbard (1995) and Vaughn (1994). Salerno (1996b) argues that the Austrian revival should be dated not from 1974, but from 1962-63, when Rothbard published Man, Economy, and State (1962), America's Great Depression (1963a), and What Has Government Done to Our Money? (1963b), the works that sparked the younger South Royalton participants' interest in Austrian economics.

3 This reference section includes a number of papers that are not mentioned in the text, but which are collected here to provide the reader with what we think is a near-complete bibliography of Austrian work on the theory of the firm. These papers have been marked with an asterisk. 


\section{REFERENCES ${ }^{3}$}

*Boudreaux, D. and Holcombe, R. (1989), 'The Coasian and Knightian Theories of the Firm', Managerial and Decision Economics, 10: 147-54.

Casson, M. (1997), Information and Organization, Oxford, Oxford University Press.

Coase, R.H. (1937), 'The Nature of the Firm', Economica (n.s.), 4 (November): 386405.

*Cowen, T. and Ellig, J. (1996), 'Market-Based Management at Koch Industries: Discovery, Dissemination, and Integration of Knowledge', Competitive Intelligence Review, 6: 4-13.

*Cowen, T. and Parker, D. (1997), Markets in the Firm: A Market Process Approach to Management, London, Institute of Economic Affairs.

Dolan, E.G. (ed.) (1976), The Foundations of Modern Austrian Economics, Kansas City, KS, Sheed \& Ward.

*Dulbecco, P. and Garrouste, P. (1999), 'Towards an Austrian Theory of the Firm', Review of Austrian Economics, 11: 43-64.

*Ellig, J. (1996), 'Organizational Economics and the Market-Based Management Framework: Toward a Common Research Agenda', Journal of Private Enterprise, 12: 1 .

*Ellig, J. (1997), 'From Austrian Economics to Market-Based Management', Journal of Private Enterprise, 13 (Special Issue): 133-46.

*Ellig, J. and Gable, W. (1993), Introduction to Market-Based Management, Fairfax, VA, Center for Market Processes.

*Fama, E. and Jensen, M.C. (1983), 'Separation of Ownership and Control', Journal of Law and Economics, 26: 301-25.

*Foss, N.J. (1993), 'More on Knight and the Theory of the Firm', Managerial and Decision Economics, 14: 269-76.

*Foss, N.J. (1994), 'The Theory of the Firm: The Austrians as Precursors and Critics of Contemporary Theory', Review of Austrian Economics, 7: 31-64.

*Foss, N.J. (1997), 'Austrian Insights and the Theory of the Firm', Advances in Austrian Economics, 4: 175-98.

*Foss, N.J. (1999), 'The Use of Knowledge in Firms', Journal of Institutional and Theoretical Economics, 155: 458-86. Reprinted in Gloria-Palermo, S., Boettke, P. and Boehme, S. (eds) (2002), Modern Austrian Economics, London, Pickering \& Chatto.

Foss, N.J. (2000), The Theory of the Firm: Critical Perspectives on Economic Organization, 4 vols, London, Routledge.

*Foss, N. and Christensen, J.F. (2001), 'A Process Approach to Corporate Coherence', Managerial and Decision Economics (forthcoming).

*Foss, K. and Foss, N. (2000), 'Economic Organization in a Process Perspective: an Explorative Discussion', in Krafft, J. (ed.), The Process of Competition, Aldershot, Edward Elgar.

*Foss, K. and Foss, N. (2001), 'Organizing Economic Experiments: the Role of Firms', forthcoming in Review of Austrian Economics.

*Foss, N.J. and Mahnke, V. (2000), 'Strategy and the Market Process Perspective', in Krafft, J. (ed.), The Process of Competition, Aldershot, Edward Elgar.

*Ghoshal, S., Moran, P. and Almeida-Costa, L. (1995), 'The Essence of the Megacorporation: Shared Context, not Structural Hierarchy', Journal of Institutional and Theoretical Economics, 151: 748-59. 
Grossman, S. and Hart, O. (1986), 'The Costs and Benefits of Ownership: A Theory of Vertical Integration', Journal of Political Economy, 94: 691-719.

Hart, O. and Moore, J. (1990), 'Property Rights and the Nature of the Firm', Journal of Political Economy, 98: 1119-58.

Holmström, B. (1979), 'Moral Hazard and Observability', Bell Journal of Economics, 10: 74-91.

Holmström, B. and Roberts, J. (1998), 'The Boundaries of the Firm Revisited', Journal of Economic Perspectives, 12: 73-94.

Hunt, S. (1999), A General Theory of Competition, London, Sage.

*Ionnanides, S. (1999), 'Towards an Austrian Perspective on the Firm', Review of Austrian Economics, 11: 77-98.

*Jacobson, R. (1992), 'The “Austrian” School of Strategy', Academy of Management Review, 17: 782-807.

Jensen, M.C. and Meckling, W. (1976), 'The Theory of the Firm: Managerial Behavior, Agency Costs and Ownership Structure', Journal of Financial Economics, 3: 305-60.

*Jensen, M.C. and Meckling, W.H. (1992), 'Specific and General Knowledge and Organizational Structure', in Lars Werin and Hans Wijkander (eds), Contract Economics, Oxford, Blackwell.

Kirzner, I.M. (1963), Market Theory and the Price System, Princeton, NJ, Van Nostrand.

Kirzner, I.M. (1966), An Essay on Capital, New York, Augustus M. Kelley.

Kirzner, I.M. (1973), Competition and Entrepreneurship, Chicago, IL, University of Chicago Press.

Klein, B., Crawford, R.G. and Alchian, A.A. (1978), 'Vertical Integration, Appropriable Rents, and the Competitive Contracting Process', Journal of Law and Economics, 21 (2): 297-326.

*Klein, P.G. (1996), 'Economic Calculation and the Limits of Organization', Review of Austrian Economics, 9: 3-28.

*Klein, P.G. (1999), 'Entrepreneurship and Corporate Governance', Quarterly Journal of Austrian Economics, 2 (2) (Summer): 19-42.

*Klein, P. and Klein, S. (2001), 'Do Entrepreneurs Make Predictable Mistakes? Evidence from Corporate Divestitures', Quarterly Journal of Austrian Economics (also this volume), 4 (2) (Summer): 3-25.

Knight, F.H. ([1921] 1965), Risk, Uncertainty, and Profit, New York, Augustus M. Kelley.

Kreps, D.M. (1996), 'Markets and Hierarchies and (Mathematical) Economic Theory', Industrial and Corporate Change, 5: 561-96.

Lachmann, L.M. (1956), Capital and Its Structure, Kansas City, KS, Sheed Andrews \& McNeel.

*Langlois, R.N. (1992), 'Orders and Organizations: Toward an Austrian Theory of Social Institutions', in Caldwell, B. and Boehm, S. (eds), Austrian Economics: Tensions and New Directions, Boston, Kluwer.

*Langlois, R.N. (1995), 'Do Firms Plan?', Constitutional Political Economy, 6: 247-61.

Langlois, R.N. (1998), 'Capabilities and the Theory of the Firm', in Foss, N.J. and Loasby, B.J. (eds), Economic Organization, Capabilities, and Coordination: Essays in Honour of George Richardson, London, Routledge.

Langlois, R.N. and Foss, N.J. (1999), 'Capabilities and Governance: the Rebirth of Production in the Theory of the Firm', KYKLOS, 52: 201-18. 
*Lewin, P. (1998), 'Capital Structure and Organizational Structure: an Austrian Market-Process Theory of the Firm', WP, School of Management, University of Texas, Dallas.

*Lewin, P. and Phelan, S. (1999), 'Firms, Strategies, and Resources', Quarterly Journal of Austrian Economics, 2 (2): 1-18.

*Malmgren, H.B. (1961), 'Information, Expectations, and the Theory of the Firm', Quarterly Journal of Economics, 75: 399-421.

*Matthews, D. (1998), 'Management versus the Market: An Exaggerated Distinction', Quarterly Journal of Austrian Economics, 1: 41-6.

*Minkler, A.P. (1993a), 'The Problem With Dispersed Knowledge: Firms in Theory and Practice', KYKLOS, 46: 569-87.

*Minkler, A.P. (1993b), 'Knowledge and Internal Organization', Journal of Economic Behavior and Organization, 21: 17-30.

Mises, L.v. (1949), Human Action, London, William Hodge.

Mises, L.v. (1957), Theory and History: An Interpretation of Social and Economic Evolution, New Haven, Yale University Press, reprint, Auburn, AL, Ludwig von Mises Institute, 1985.

Mises, L.v. (1962), The Ultimate Foundation of Economic Science: An Essay on Method, Princeton, NJ, D. Van Nostrand.

*Moss, L. (1991), 'The Chicago Intellectual Property Rights Tradition and the Reconciliation of Coase and Hayek', Eastern Economic Journal, 17: 145-56.

Penrose, E.T. (1959), The Theory of the Growth of the Firm, Oxford, Oxford University Press.

Richardson, G.B. (1960), Information and Investment: A Study in the Working of the Competitive Economy, Oxford, Clarendon Press.

Rothbard, M.N. (1956), 'Toward a Reconstruction of Utility and Welfare Economics', in Sennholz, M. (ed.), On Freedom and Free Enterprise: Essays in Honor of Ludwig von Mises, Princeton, NJ, Van Nostrand, pp. 224-62.

Rothbard, M.N. (1962), Man, Economy, and State, Auburn, AL, Ludwig von Mises Institute, 1993.

Rothbard, M.N. (1963a), America's Great Depression, 2nd revised edn, New York, Richardson and Snyder, 1983.

Rothbard, M.N. (1963b), What Has Government Done to Our Money? Auburn, AL, Ludwig von Mises Institute, 1990.

Rothbard, M.N. (1995), 'The Present State of Austrian Economics', in idem (1997), The Logic of Action, Cheltenham, Edward Elgar, vol. 1, pp. 111-72.

Salerno, J.T. (1999), 'The Place of Human Action in the Development of Modern Economic Thought', Quarterly Journal of Austrian Economics, 2: $35-65$.

*Sautet, F. (1998), An Entrepreneurial Theory of the Firm, London, Routledge.

Spadaro, L.M. (ed.) (1978), New Directions in Austrian Economics, Kansas City, KS, Sheed Andrews \& McMeel.

Teece, D.J., Rumelt, R.P., Dosi, G. and Winter, S.G. (1994), 'Understanding Corporate Coherence: Theory and Evidence', Journal of Economic Behavior and Organization, 23: 1-30.

*Tullock, G. (1969), ‘The New Theory of Corporations', in Streissler, E. (ed.), Roads to Freedom: Essays in Honour of Friedrich A. von Hayek, London, Routledge \& Kegan Paul.

Vaughn, K.I. (1994), Austrian Economics in America: The Migration of a Tradition, Cambridge, Cambridge University Press. 
*Vihanto, M. (1992), 'Contracting Costs and Entrepreneurial Discovery', Finnish Journal of Business Economics, 41 (4), 353-70.

*Westgren, R.E. (1995), 'Firm Resources, Industrial Organization and Austrian Economics: The Bases for a New Strategic Management Approach to Competitiveness', in Peters, G.H. and Hedley, D.D. (eds), Agricultural competitiveness: Market forces and policy choice: Proceedings of the TwentySecond International Conference of Agricultural Economists, Aldershot, Dartmouth. Williamson, O.E. (1985), The Economic Institutions of Capitalism, New York, Free Press.

*Witt, U. (1999), 'Do Entrepreneurs Need Firms? A Contribution to a Missing Chapter in Austrian Economics', Review of Austrian Economics, 11: 99-110.

*Young, G., Smith, K.G. and Grimm, C.M. (1996), "“Austrian" and Industrial Organization Perspectives on Firm-level Competitive Activity and Performance', Organization Science, 7: 243-54.

Yu, T. (1999), 'Toward a Praxeological Theory of the Firm', Review of Austrian Economics, 12: 25-41. 